\title{
Pengembangan Karakter Kepribadian Anak Usia Dini (Studi Pada PAUD Islam Terpadu Di Kabupaten Magelang Tahun 2015)
}

\author{
Jaka Siswanta \\ Institut Agama Islam Negeri Salatiga \\ jaksis71@yaboo.co.id
}

\begin{abstract}
The purpose of this study is to describe the values developed in the development of the child'spersonality character, describe the implementation of the development of children's personality traits, the strategy of developing the personality character of children, the constraints in the implementation of the development of child personality character in the Integrated Islamic School of Magelang District 2015. With a qualitative approach using purposive sampling technique. The results pointed. PAUD Integrated Aisyiyah Insan Robbani Muntilan and Islamic Early Childhood Ibnu Hadjar refers to the provisions of the implementation of Character Education established by the Ministry of National Education, early childhood education developed values of personality traits based on the value determined by the school. Implementation of character formation is done as an effort to form the character of child's personality. Character development strategy is done by the method of playing while singing, exemplary methods, methods of advice, methods of supervision and method of habituation. Constraints, especially parents support factors related to school policy in the development of children's personality traits.
\end{abstract}

Keywords: Character Values, Personality, Early Childhood

\begin{abstract}
Abstrak
Tujuan penelitian ini adalab mendeskripsikan nilai-nilai yang dikembangkan dalam pengembangan karakter kepribadian anak, mendeskripsikan pelaksanaan pengembangan karakterkepribadiananak, strategipengembangankarakterkepribadian anak, kendala-kendala dalam pelaksanaan pengembangan karakter kepribadian anak di PAUD Islam Terpadu Kabupaten Magelang tabun 2015.Denganpendekatan kualitatif menggunakan teknik purposive sampling.Hasil penelitian menunjukakan. PAUD Terpadu Aisyiyah Insan Robbani Muntilan dan PAUD Islam Terpadu Ibnu Hadjar mengacu ketentuan pelaksanaan Pendidikan Karakter yang ditetapkan oleh Kementerian Pendidikan Nasional, PAUD BIAS mengembangkan nilai-nilai karakter kepribadian berdasar nilai yang ditentukan pihak sekolah. Pelaksanaan pembentukan karakter dilakukan sebagai upaya pembentukan karakter kepribadian anak.Strategi pengembangan karakter dilakukan dengan metode bermain sambil bernyanyi, metode keteladanan, metode nasibat, metode pengawasan dan metode pembiasaan.Kendalakendala khususnya faktor dukungan orang tua terkait dengan kebijakan sekolah dalam pengembangan karakter kepribadian anak.
\end{abstract}

Kata Kunci : Nilai-nilai Karakter, Kepribadian, Anak Usia Dini

Permalink/DOI:http://dx.doi.org/10.18326/infsl3.v11i1.97-118 


\section{Pendahuluan}

Eksistensi Pendidikan Anak Usia Dini (PAUD) merupakan hal teramat penting dalam perkembangan kepribadian anak, terutama pada saat dirinya melewati masa-masa keemasannya (fase golden age). Pada masa ini terjadi kematangan fungsi fisik dan psikis yang siap merespon stimulasi yang diberikan oleh lingkungan. Masa ini juga merupakan masa peletak dasar untuk mengembangkan kemampuan kognitif, motorik, bahasa, sosio emosional, agama dan moral. Selain itu, pada masa keemasan, dalam diri anak dapat dibentuk/dikembangkan karakter kepribadiannya, aktivitas bermain-nya dan sebagainya.

Pengembangan karakter anak tidak sekejap muncul. Karakter perlu dibentuk dan dikembangkan sejak anak usia dini. Goleman (2003) mencatat bahwa kegagalan penanaman karakter pada masa ini akan membentuk pribadi yang bermasalah di masa dewasa kelak. Keberhasilan seseorang di masyarakat ditentukan 80\% oleh kecerdasan emosi (EQ) dan 20\% oleh kecerdasan intelektual lainnya (IQ). Orang yang mempunyai kecerdasan emosi tinggi adalah orang yang berkarakter baik. Bila karakter anak dibentuk dengan baik, kelak ia akan memiliki kepribadian yang baik di masa depannya. Demikian pula, jika karakter kepribadian anak tidak dibentuk dengan baik, kelak ia-pun dapat memiliki kepribadian yang tidak baik pula.

Menurut Megawangi (2004), anak-anak akan tumbuh menjadi pribadi yang berkarakter apabila dapat tumbuh pada lingkungan yang berkarakter, sehingga fitrah setiap anak yang dilahirkan suci dapat berkembang segara optimal. Mengingat lingkungan anak bukan saja lingkungan keluarga yang sifatnya mikro, maka semua pihak - keluarga, sekolah, media massa, komunitas bisnis, dan sebagainya - turut andil dalam perkembangan karakter anak.

Pembentukan karakter anak mencakup: pertama, cinta Tuhan dan ciptaannya; kedua, kemandirian dan tanggung jawab; ketiga, kejujuran dan kebijakan; keempat, dermawan, suka menolong, dan gotong royong; kelima, percaya diri, kreatif dan pekerja keras; keenam, kepemimpinan dan keadilan; ketujuh, baik dan rendah hati; kedelapan, toleransi, kedamaian dan kesatuan, (Megawangi, 
:2010). Pengembangan karakter kepribadian semacam ini, lebih banyak dilakukan di lingkungan sekolah. Sekolah untuk anak pada fase emas bukanlah sekolah yang monoton, tapi harus sekolah yang menyenangkan dengan penetrasi edukasi lewat permainan, termasuk ajaran agama dan nilai moral.

Arlene Eisenberg, Heidi E. Murkof, dan Sandee E. Hathaway; (2002) dalam Megawangi (2010) menegaskan bahwa melalui sekolah/ lingkungan pendidikan, anak dapat melakukan/memperoleh hal-hal; (1) Mengenal dunia sekitar. (2) Meningkatkan harga diri. (3) Membangun kemampuan bersosialisasi. (4) Kesempatan untuk menyalurkan emosi. Berbagai jenis emosi seperti marah, takut, sedih dan cemas disalurkan melalui bermain peran/role playing. (5) Meningkatkan kemampuan bahasa. (6) Menstimulasi kreativitas dan imajinasi. (7) Mengembangkan kemampuan motorik halus dan koordinasi tangan dan mata. (8) Mengembangkan kemampuan motorik kasar.

Beragam aktivitas pengembangan potensi anak sebagaimana tersebut di atas, lebih banyak dapat dilakukan di lingkungan PAUD/sekolah. Oleh karena itu, lembaga PAUD semestinya sadar benar dengan berbagai kebutuhan perkembangan anak, sebagaimana terurai di atas. Kiranya tidak seluruh lembaga PAUD dapat memberikan fungsi maksimal dalam pengembangan potensi anak terkait dengan sarana-prasarana dan berbagai perangkat pendukungnya termasuk eksistensi dan potensi pengasuhnya dalam mengembangkan kemampuan kepribadian anak asuhnya.

Survey awal yang peneliti lakukan pada beberapa lembaga PAUD Islam Terpadu, seperti di PAUD Terpadu Aisyiyah "Insan Robbani" Muntilan, PAUD Islam Terpadu "BIAS" Muntilan dan PAUD Islam Terpadu "Ibnu Hajar" Sirahan Salam; merupakan bagian kecil dari lembaga-lembaga PAUD Islam yang memperlihatkan eksistensinya dalam pembentukan/pengembangan karakter kepribadian kepada anak asuhnya. Bagaimana lembaga-lembaga tersebut menyelenggarakan pendidikan dalam mengembangkan karakter kepripadian anak, nilai-nilai apasaja dan strategi apa yang dipilih serta kendala yang dialami sekolah dalam proses pengembangan karakter kepribadian anak perlu dikaji melalui kegiatan penelitian ini. 


\section{Pengembangan Karakter Kepribadian Anak Usia Dini}

Pengembangan karakter kepribadian penting sekali dilakukan ketika anak dalam masa-masa usia dini. Sigmund Freud menyebutkan bahwa kepribadian sebagian besar dibentuk pada usia lima tahun. Awal perkembangan kepribadian berpengaruh besar dalam pembentukan kepribadian dan terus mempengaruhi perilaku di kemudian hari. Sementara, Erikson dengan teori perkembangan psiko-sosial, mengambil dasar dari teori psikoanalitik Sigmund Freud, namun Erik Erikson tidak sependapat dengan Freud yang mengatakan bahwa reaksi masa dewasa adalah hasil dari pengalaman-pengalaman masa kanak-kanak, khususnya di usia 5 sampai 6 tahun awal. Menurut Erikson, lingkungan di mana anak hidup sangat penting untuk memberikan pertumbuhan, penyesuaian, sumber kesadaran diri dan identitas. Erik Erikson percaya bahwa setiap manusia berjalan melalui sejumlah tahap untuk mencapai pembangunan penuhnya, melewati dari lahir sampai mati (http:// konselingindonesia.com/ : 2010) diakses pada Juni 2015.

Vigotsky memandang bahwa sistem sosial sangat penting dalam perkembangan kognitif anak.Orang tua, guru dan teman berinteraksi dengan anak dan berkolaborasi untuk mengembangkan suatu pengertian.Jadi belajar terjadi dalam konteks sosial, dan muncul suatu istilah Zona Perkembangan Proksimal (ZPD). ZPD diartikan sebagai daerah potensial seorang anak untuk belajar, atau suatu tahap dimana kemampuan anak dapat ditingkatkan dengan bantuan orang yang lebih ahli. Daerah ini merupakan jarak antara tahap perkembanan aktual anak yaitu ditandai dengan perkembangan potensial dimana kemampuan pemecahan masalah harus melalui bantuan orang lain yang mampu. Oleh karena itu dalam mengembangkan setiap kemampuan anak diperlukan scaffolding atau bantuan arahan agar anak pada akhirnya menguasai keterampilan tersebut secara independen. Vigotsky meyakini bahwa pikiran anak berkembang melalui: (1) Mengambil bagian dalam dialog yang kooperatif dengan lawan yang terampil dalam tugas di luar Zone Proximal Development; (2) Menggunakan apa yang dikatakan pendidik yang ahli dengan apa yang dilakukan. Berbeda dengan Piaget yang memfokuskan pada perkembangan berfikir dalam diri anak (intrinsik), Vigotsky menekankan bahwa 
perkembangan kognitif seorang anak sangat dipengaruhi oleh sosial dan budaya anak tersebut tinggal. Setiap budaya memberikan pengaruh pada pembentukan keyakinan, nilai, norma kesopanan serta metode dalam memecahkan masalah sebagai alat dalam beradaptasi secara intelektual. Budayalah yang mengajari anak untuk berfikir dan apa yang seharusnya dilakukan. (http://valmband. multiply.com/journal/item/11?\&show_interstitial=1\&u=\%2Fjournal $\%$ 2Fitem. Diakses Juni 2015).

\section{Pengembangan Nilai-Nilai Karakter Kepribadian Anak Usia Dini}

Pengembangan Nilai-Nilai Karakter sangat penting dimulai sejak dini. Sebab falsafah menanam sekarang menuai hari esok adalah sebuah proses yang harus dilakukan dalam rangka membentuk karakter anak bangsa. Pada usia kanak-kanak atau yang biasa disebut para ahli psikologi sebagai usia emas (golden age) terbukti sangat menentukan kemampuan anak dalam mengembangkan potensinya. Hasil penelitian menunjukkan bahwa sekitar 50 persen variabilitas kecerdasan orang dewasa sudah terjadi ketika anak berusia empat tahun. Peningkatan 30 persen berikutnya terjadi pada usia delapan tahun, dan 20 persen sisanya pada pertengahan atau akhir dasawarsa kedua (Zhao, dkk, 2002).

Pengembangan nilai-nilai karakter kepribadian dalam diri anak dipengaruhi oleh hereditas maupun lingkungan. Perilaku seorang anak sering kali tidak jauh dai perilaku ayah dan ibunya. Lingkungan sosial maupun lingkungan alam juga turut memberi kontribusi terhadap pembentukan karakter seseorang.Seorang anak yang hidup di tengah lingkungan sosial yang keras, seperti di daerah padat penduduk, metropolitan, biasanya cenderung berperilaku antisosial, keras, emosional dan sebagainya.Sementara itu anak yang hidup di lingkungan yang gersang, panas, dan tandus, pada umumnya juga memiliki temperamen yang keras pula.

Pengembangan karakter dalam diri anak diarahkan pada nilai, sikap, dan perilaku yang memancarkan akhlak mulia atau budi pekerti luhur. Nilai-nilai positif yang seharusnya dimiliki seseorang menurut ajaran budi pekerti yang luhur adalah amal saleh, 
amanah, antisipatif, baik sangka, bekerja keras, beradab, berani berbuat benar, berani memikul resiko, berdisiplin, berhati lapang, berhati lembut, beriman dan bertaqwa, berinisiatif, berkemauan keras, berkepribadian, berpikiran jauh ke depan, bersahaja, bersemangat, bersifat konstruktif, bersyukur, bertanggung jawab, bertenggang rasa, bijaksana, cerdas, cermat, demokratis, dinamis, efisien, empati, gigih, hemat, ikhlas, jujur, kesatria, komitmen, kooperatif, kosmopolitan (mendunia), kreatif, kukuh hati, lugas, mandiri, manusiawi, mawas diri, mencintai ilmu, menghargai karya orang lain, menghargai kesehatan, menghargai pendapat orang lain, menghargai waktu, patriotik, pemaaf, pemurah, pengabdian, berpengendalian diri, produktif, rajin, ramah, rasa indah, rasa kasih sayang,rasa keterikatan, rasa malu, rasa memiliki, rasa percaya diri, rela berkorban, rendah hati, sabar, semangat kebersamaan, setia, siap mental, sikap adil, sikap hormat, sikap nalar, sikap tertib, sopan santun, sportif, susila, taat asas, takut bersalah, tangguh, tawakal, tegar, tegas, tekun, tepat janji, terbuka, ulet, dan sejenisnya.

Thomas Lickona Terdapat sembilan pilar karakter yang berasal dari nilai-nilai luhur universal, yaitu: pertama, karakter cinta Tuhan dan segenap ciptaan-Nya; kedua, kemandirian dan tanggungjawab; ketiga, kejujuran/amanah, diplomatis; keempat, hormat dan santun; kelima, dermawan, suka tolong-menolong dan gotong royong/kerjasama; keenam, percaya diri dan pekerja keras; ketujuh, kepemimpinan dan keadilan; kedelapan, baik dan rendah hati, dan; kesembilan, karakter toleransi, kedamaian, dan kesatuan. Kesembilan pilar karakter itu, diajarkan secara sistematis dalam model pendidikan holistik menggunakan metode knowing the good, feeling the good, dan acting the good.Knowing the good bisa mudah diajarkan sebab pengetahuan bersifat kognitif saja. Setelah knowing the good harus ditumbuhkan feeling loving the good, yakni bagaimana merasakan dan mencintai kebajikan menjadi engine yang bisa membuat orang senantiasa mau berbuat sesuatu kebaikan. Sehingga tumbuh kesadaran bahwa, orang mau melakukan perilaku kebajikan karena dia cinta dengan perilaku kebajikan itu.Setelah terbiasa melakukan kebajikan, maka acting the good itu berubah menjadi kebiasaan.Lebih lanjut dijelaskan bahwa pendidikan karakter adalah segala sesuatu yang dilakukan guru, yang mampu 
mempengaruhi karakter peserta didik. Guru membantu membentuk watak peserta didik. Hal ini mencakup keteladanan bagaimana perilaku guru, cara guru berbicara atau menyampaikan materi, bagaimana guru bertoleransi, dan berbagai hal terkait lainnya.

\section{Strategi Pengembangan Karakter Kepribadian anak Usia Dini}

\section{Metode bermain}

Fungsi bermain bagi anak adalah inti dari proses pembelajaran. Melalui bermain anak bisa membangun pemahaman dan pengetahuan. Dengan kegiatan bermain yang yang positif, anak dapat melatih perkembangan otak dan motorik seperti melatih menggunakan otot tubuhnya dan menstimulus penginderaannya. Bermain menjadikan anak mampu menjelajahi dunia sekitamya, mengenali lingkungan tempatia tinggal termasuk mengenali diri sendiri. Sehingga kemampuan fisik anak semakin terlatih, begitu pula dengan kemampuan kognitif dan kemampuan sosialnya. Setiap anak juga dapat mengembangkan keterampilan emosinya, rasa percaya diri pada orang lain, kemandirian, dan keberanian untuk berinisiatif. Jadi kegiatan bermain merupakan sarana melatih keterampilan yang dibutuhkan anak untuk menjadi individual yang kompeten dan membuat anak menyadari kemampuan dan kelebihannya (Musfiroh,2008:56).

\section{Metode Keteladanan}

Keteladanan dalam pendidikan adalah cara yang paling efektif dan berhasil dalam mempersiapkan anak dari segi akhlak, membentuk mental dan sosialnya. Hal ini dikarenakan pendidik adalah panutan atau idola dalam pandangan anak dan contoh yang baik di mata mereka. Anak akan meniru baik akhlaknya,perkataannya, perbuatannya dan akan senantiasa tertanam dalam diri anak. Oleh karena itu metode keteladanan menjadi faktor penting dalam menentukan baik dan buruknya kepribadian anak (Ulwan, 2012: 516).Dalam mendidik anak tanpa adanya keteladanan, pendidikan apapun tidak berguna bagi anak dan nasihat apapun tidak berpengaruh untuknya. Mudah bagi pendidik untuk memberikan 
satu pelajaran kepada anak, namun sangat sulit bagi anak untuk mengikutinya ketika ia melihat orang yang memberikan pelajaran tersebut tidak mempraktikkan apa yang diajarkan.

Memberikan keteladanan (contoh) merupakan salah satu cara terpenting dalam mendidik anak. Apabila anak telah kehilangan suri tauladannya, maka anak akan merasa kehilangan segala sesuatunya. Memberikan teladan yang baik merupakan metode yang paling membekas pada anak didik. Sehingga diharapkan dengan metode ini anak akan memilki akhlak yang mulia, misalkan saja bersikap ramah dan sopan tehadap orang tua ataupun yang lebih tua darinya, berbuat baik kepada temannya, jujur dan juga mau minta maaf bila berbuat salah.

\section{Metode Pembiasaan}

Pembiasaan merupakan proses pembentukan sikap dan perilaku yang relative menetap melalui proses pembelajaran yang beruang-ulang. Pembiasaan sangat efektif untuk diterapkan pada masa usia dini, karena memiliki rekaman atau ingatan yang kuat dan kondisi kepribadian yang belum matang sehingga mereka mudah terlarut dengan kebiasaan-kebiasaan yang mereka lakukan seharihari (Arief, 2002:110).

Penerapan metode pembiasaan dilakukan dengan memberikan penjelasan-penjelasan seperlunya makna gerakan-gerakan, perbuatan-perbuatan dan ucapan-ucapan dengan memperhatikan taraf kematangan anak. Seperti halnya dalam menanamkan nilainilai agama Islam pada anak, hendaknya semakin banyak diberikan latihan-latihan pembiasaan nilai keagamaan karena anak di usia ini masih suka meniru kegitan-kegiatan yang dilakukan oleh orang disekitarnya. Diharapkan dengan metode pembiasaan, maka anak akan berproses secara langsung dengan lingkungan dan pendidikan yang diajarkan. 


\section{Metode Nasehat}

Metode pendidikan dengan nasehat adalah memberikan nasehat atau petuah yang baik kepada anak sehingga anak meniru dan melaksanakan apa yang dilakukan oleh pendidik dan orang tua. Metode nasehat akan berjalan baik pada seseorang jika seseorang yang menasehati juga melaksanakan apa yang dinasehatkan yaitu dibarengi dengan teladan atau uswah. Bila tersedia teladan yang baik maka nasehat akan berpengaruh terhadap jiwanya dan akan menjadi suatu yang sangat besar manfaatnya dalam pendidikan rohani(Harun, 1993: 334). Fungsi metode nasehat adalah untuk menunjukkan kebaikan dan keburukan, karena tidak semua orang bisamenangkap nilai kebaikan dan keburukan. Oleh karena itu, anak memerlukan nasehat, nasehat yang lembut, halus, tetapi berbekas, yang bisa membuat anak menjadi baik dan tetap berakhlak mulia.

\section{Metode Perhatian/Pengawasan}

Maksud dari pendidikan perhatian adalah senantiasa mencurahkan perhatian penuh dan mengikuti perkembangan anak dan mengawasinya dalam membentuk akidah, akhlak, mental, social dan juga terus mengecek keadaannya dalam pendidikan fisik dan intelektualnya. Metode ini merupakan salah satu asas yang kuat dalam membentuk muslim yang hakiki sebagai dasar untuk membangun fondasi Islam yang kokoh.

\section{Metode Hukuman}

Metode hukuman merupakan suatu cara yang dapat digunakan oleh guru dalam mendidik anak apabila penggunaan metodemetode yang lain tidak mampu membuat anak berubah menjadi lebih baik. Dalam menghukum anak, tidak hanya menggunakan pukulan saja, akan tetapi bisa menggunakan sesuatu yang bersifat mendidik. 


\section{Kendala Pengembangan Karakter Kepribadian anak Usia Dini}

Kendala pengembangan karakter kepribadian anak usia dini sering kali bertolak dari berbagai kegiatan yang melingkupi pentingnya pengembangankarakter kepribadian anak. Ari Ginanjar Agustian (2005: 39), menyebut beberapa hal mendasar yang mendorong pentingnya pengembangankarakter kepribadian anak. Pertama, makin kompleksnya permasalahan kehidupandi sekitar anak, termasuk di dalamnya perkembangan IPTEK yang banyak memberikan tekanan pada anak dan memengaruhi perkembangan emosi maupun sosialanak. Kedua, penanaman kesadaran bahwa anak adalah praktisi dan investasi masa depan yang perlu dipersiapkan secara maksimal,baik aspek perkembangan emosinya maupun keterampilan sosialnya. Ketiga karena rentang usia penting pada anak terbatas. Jadi, harus difasilitasi seoptimal mungkin agar tidak ada satu fase pun yang terlewatkan. Keempat, ternyata anak tidak bisa hidup dan berkembang dengan IQ semata, tetapi EI jauh lebih dibutuhkan sebagai bekal kehidupan.

Pendidikan Karakter merupakan program baru yang diprioritaskan Kementrian Pendidikan dan Kebudayaan.Sebagai program baru masih menghadapi banyak kendala.Kendala-kendala tersebut adalah; a) Nilai-nilai karakter yang dikembangkan di sekolah belum terjabarkan dalam indikator yang representatif. Indikator yang tidak representatif dan baik tersebut menyebabkan kesulitan dalam mengukur ketercapaiannya, b) Sekolah belum dapat memilih nilainilai karakter yang sesuai dengan visinya. Jumlah nilai-nilai karakter demikian banyak, berdampak pada gerakan membangun karakter di sekolah menjadi kurang terarah dan fokus, sehingga tidak jelas pula monitoring dan penilaiannya, c) Pemahaman guru tentang konsep Pendidikan Karakter yang masih belum menyeluruh. d) Guru belum memiliki kompetensi yang memadai untuk mengintegrasikan nilai-niai karakter pada kegiatan pembelajaran. e) Guru belum sepenuhnya menjadi teladan atas nilai-nilai karakter yang dipilihnya. Permasalahan yang paling berat adalah peran guru untuk menjadi teladan dalam mewujudkan nilai-nilai karakter secara khusus sesuai dengan nilai-nilai karakter umum di sekolah. 


\section{Metodologi Penelitian}

Penelitian dilakukan dengan pendekatan kualitatif. Kajian pengembangan karakter kepribadian anak usia dini akan dilakukan melalui wawancara secara mendalam dan pengamatan intensif dalam kerangka mengungkap berbagai problem penelitian.

Lokasi penelitian dilakukan PAUD Terpadu Aisyiyah Insan Robani Ngadisalam, Gunungpring Kec. Muntilan, Pendidikan Anak Usia Dini (PAUD) BIAS (Bina Anak Sholeh) Muntilan dan PAUD Islam Terpadu Ibnu Hajar Sirahan Kec. Salam Kabupaten Magelang. Penentuan subyek penelitian dilakukan dengan menggunakan teknik purposive sampling.Pengumpulan data dalam penelitian ini menggunakan teknik pengamatan dan wawancara. Analisis data dalam penelitian ini ditempuh secara induktif.Kegiatannya meliputi; reduksi data, penyajian data, dan penarikan kesimpulan (verifikasi).

\section{Analisis}

Pengembangan Nilai-Nilai Karakter Kepribadian Anak Di PAUD Islam Terpadu Kabupaten Magelang

Nilai-Nilai Karakter Yang Dikembangkan di PAUD Islam Terpadu Insan Robbani Muntilan

PAUD Islam Terpadu Insan Robbani Muntilan menekankan visi utamanya dalam mendidik/membina anak-anak yang dipercayakan masyarakat di lembaga PAUD tersebut. Sebagai lembaga Pendidikan Anak Usia Dini di bawah naungan Aisyiyah Ranting Muntilan sekaligus bernaung pula di bawah Bidang Pendidikan Non Formal- In Formal, Dinas Pendidikan Kabupaten Magelang, maka pesan-pesan pembentukan karakter kepribadian para siswa mengacu/mengikuti kebijakan pendidikan karakter yang ditetapkan oleh Dinas Pendidikan Nasional. Maka itu, nilai-nilai karakter kepribadian yang dikembangkan di PAUD meliputi; Religius,Jujur ,Toleransi,Disiplin, Kerja Keras, Kreatif, Mandiri, Demokratis, Rasa Ingin Tahu, Semangat Kebangsaan, Cinta Tanah Air, Menghargai Prestasi, Bersahabat/Komunikatif, Cinta Damai, Gemar Membaca, Peduli Lingkungan, Peduli Sosial. 
Penanaman nilai-nilai karakter tersebut menjadi bagian dari implementasi binaan kepribadian dari para siswa di PAUD.Pihak PAUD menyadari sepenuhnya bahwa simbul-simbul nilai karakter tidak terpajang di area manapun di lingkungan PAUD, demikian pula kadang-kadang diantara para guru/pengasuh juga lupa/tidak sempat untuk menuliskan pesan-pesan karakter yang akan diajarkan dalam Rencana Kegiatan Harian mereka. Namun demikian implementasi isi dari nilai-nilai karakter, terealisasi secara nyata melalui berbagai kegiatan yang diikuti seluruh anak/siswa PAUD, baik dalam kegiatan pembelajaran di sekolah maupun pada saat anak-anak melakukan kegiatan kunjungan lapangan (field trip). Format RKH telah memasukkan pesan nilai-nilai karakter yang menjadi dasar dalam pembinaan kepribadian anak/siswa di lingkungan PAUD.

Rencana Kegiatan Harian yang disiapkan oleh para guru PAUD, ternyata tidak sekedar sebagai kelengkapan administrasi pembelajaran melainkan benar-benar sebagai catatan kegiatan pembelajaran secara tertulis dan terencana. Namun dalam hal memasukkan pesan-pesan nilai karakter yang dikembangkan dalam Rencana Kegiatan Harian, tidak setiap kolom karakter yang dikembangkan diisi dengan lengkap olehnya maupun guruguru lain di PAUD. Begitupun demikian, komitmen menanamkan karakter kepribadian yang mantab tetap dilakukan oleh PAUD Islam Terpadu Insan Robbani Muntilan kepada seluruh siswanya.

Simbul-simbul nilai karakter yang berada di lingkungan sekolah memang tidak dipajang secara eksplisit.Beberapa lukisan dinding kelas mengetengahkan gambar-gambar yang mencerminkan tema kegiatan, seperti gambar hewan laut, gambar profesi, gambar kegiatan anak-anak.Gambar-gambar tersebut, secara tersirat juga memperlihatkan pesan nilai karakter, seperti gambar anak yang sedang menata buku di rak buku, gambar orang-orang secara berurutan sedang mengantri, gambar anak-anak menata taman dan sebagainya.

Selain gambar-gambar ada pula kegiatan-kegiatan yang bermuatan pesan karakter dalam rangka pembentukan kepribadian siswa yang tertib dan teratur. Seperti ketika, kegiatan toilet training, anak-anak diarahkan untuk mengikuti kegiatan mulai dari berdoa 
masuk kamar kecil, melepas celana, keluar ruangan menuju kamar kecil secara berurutan dan teratur, kembali lagi ke ruangan kelas untuk memakai celana kembali yang telah ditata dengan baik oleh para guru/pengasuh kelas yang bersangkutan.

Visualisasi gambar-gambar memperlihatkan betapa besar kesungguhan PAUD Terpadu Aisyiyah Insan Robbani Muntilan dalam menempatkan nilai-nilai karakter dalam membentuk kepribadian siswa di PAUD-nya.Nilai-nilai karekter kepribadian yang hidup dan lestari dalam lingkungan PAUD Terpadu Aisyiyah Insan Robbani Muntilan merupakan asset berharga dalam membentuk calon generasi penerus bangsa yang dapat diandalkan oleh bangsa dan negaranya.

\section{Nilai Karakter Yang Dikembangkan di PAUD Islam Terpadu BIAS Muntilan}

Nilai-nilai karakter/kepribadian yang dikembangkan dalam penyelenggaraan pendidikan di PAUD BIAS Muntilan merupakan ikon yang menjadi kebanggaan bagi pihak sekolah sejalan dengan esensi nama lembaga tersebut yang mengklaim sebagai lembaga Bina Anak Sholeh. Sejalan dengan nama itu, pihak sekolah menetapkan 18 nilai-nilai karakter yang lebih akrab mereka sebut dengan istilah akhlak aplikatif.

Eksistensi delapan belas akhlak aplikatif tersebut tidak merupakan keserta-mertaan dengan delapanbelas nilai karakter yang dikembangkan oleh dinas pendidikan. Delapan belas akhlak aplikatif tersebut dikembangkan oleh Yayasan Bina Anak Sholeh yang telah terlebih dahulu lahir diberbagai tempat lainnya.Melalui delapan akhlak aplikatif itulah, PAUD BIAS Muntilan mencoba untuk membina siswanya sesuai dengan yang diharapkan oleh masyarakat.

Delapan belas akhlak aplikatif sebagaimana disebut di atas terdiri dariRefleksi berinfak dan shodaqoh, Antusias ibadah ta'aluh,Kepedulian dan empati, Kerja sama, Berani, Sabar, Kejujuran, Banyak akal, Adil, Sikap respek, Suka menolong, Mandiri dan percaya diri, Tanggung jawab, Humor, Loyalitas, Keteguhan 
hati dan komitmen, Toleransi, Rasa bangga

Delapan belas akhlak aplikatif harus menjadi menu harian yang setiap saat ditemukan oleh anak-anak.Oleh karena itu, nilainilai dari delapan belas akhlak aplikatif dipampangkan sebagai etalage yang bergantungan di lokasi anak-anak beraktivitas dan bermain-main dalam keseharian.Tujuan dari pemajangan nilai-nilai yang dituliskan di papan kertas bergantungan itu, agar para guru/ pengasuh bisa setiap saat menunjukkan kepada para siswa nilainilai karakter yang sekurang-kurangnya dapat mereka kenalkan, tanamkan dan darah-dagingkan dalam kepribadian setiap anak di lingkungan PAUD BIAS Muntilan.Dalam konteks ini, para guru dan pengasuh tidak lagi lupa dengan misi penanaman akhlak aplikatifnya kepada seluruh siswa di lingkungan PAUD BIAS Muntilan.

Secara konteks bangunan/area sekolah, PAUD BIASMuntilan berupaya untuk memperlihatkan layanan pendidikan dan pembinaan anak melalui penataan etalage sekolah yang tengah memperlihatkan upayanya dalam membina anak sholeh di sekolah.Seperti dokumen foto yang memperlihatkan lingkungan sekolah dengan nilai-nilai karakter kepribadian yang Ustadzah Siti Fatimah sebut dengan istilah akblak aplikatif yang berjumlah 18 nilai.Delapan belas akhlak aplikatif ini di gantung di atas area main anak.

Perkembangan aspek kepribadian yang dituangkan dalam delapanbelas akhlak aplikatif di PAUD BIAS Muntilan, secara cermat terpantau pada setiap siswa yang mengikuti pendidikan di lembaga tersebut.Berdasarkan dokumen raport, terlihat bahwa delapan belas akhlak aplikatif menjadi sasaran penting bentukan kepribadian siswa yang harus dilaporkan secara berkala oleh pihak PAUD kepada orangtua siswa masing-masing.

\section{Nilai Karakter Yang Dikembangkan di PAUD Islam Terpadu Ibnu Hadjar Sirahan, Kec. Salam.}

Nilai Karakter yang dikembangkan di PAUD Islam Terpadu Ibnu Hadjar Sirahan, Kec. Salam, secara normatif sejalan dengan kebijakan Kementerian Pendidikan Nasional. Nilai-nilai pendidikan karakter yang dikembangkan, meliputi; Religius,Jujur, Toleransi, 
Disiplin,Kerja Keras, Kreatif,Mandiri, Demokratis, Rasa Ingin Tahu, Semangat Kebangsaan, Cinta Tanah Air, Menghargai Prestasi, Bersahabat/Komunikatif, Cinta Damai, Gemar Membaca, Peduli Lingkungan,Peduli Sosial dan Tanggung-jawab.

Nilai- nilai karakter sebagaimana terurai di atas, oleh para guru/pengasuh di PAUD Islam Terpadu Ibnu Hadjar Sirahan, Kec. Salam, kurang dipahami sebagai pedoman dalam menanamkan karakter kepribadian para siswa melalui berbagai kegiatan pembelajaran di PAUD.Para guru/pengasuh PAUD merasa kesulitan untuk mengimplementasikan seluruh nilai karakter tersebut dalam kegiatan pembelajaran kepada para siswanya.Oleh karena itu, dari sisi penyiapan adfministrasi pembelajaran, penataan lingkungan belajar, penataan lingkungan PAUD atau sekolah juga kurang memperlihatkan pesan-pesan karakter yang mestinya mendukung pengembangan karakter kepribadian anak.

\section{Pelaksanaan Pengembangan Karakter Kepribadian Anak di PAUD Islam Terpadu Kabupaten Magelang}

Pelaksanaan pengembangan karakter kepribadian anak di PAUD Islam Terpadu Kabupaten Magelang meliputi: karakter kepribadian Kereligiusan; Karakter Kejujuran, Keberanian mengambil risiko, Kecerdasan, Ketangguhan, Kedemokratisan, Kemandirian dan Kepedulian, serta Berpikir logis, kritis, kreatif, dan inovatif; dan karakter Kepemimpinan, Percaya Diri, Kerjasama, Kerja Keras dan Tanggung Jawab.

\section{Pengembangan karakter kepribadian Kereligiusan}

Pelaksanaan pengembangan karakter kepribadian religius menjadi bagian penting yang terjadi pada PAUD Terpadu Aisyiyah Insan Robbani Muntilan, PAUD Bias Muntilan dan PAUD Islam Terpadu Ibnu Hadjar Sirahan, Salam.Dalam proses pembinaan dan pengembangan nilai-nilai agama bagi anak, muatan materi pembelajarannya harus bersifat: Aplikatif: materi pembelajaran bersifat terapan, yang berkaitan dengan kegiatan rutin anak seharihari dan sangat dibutuhkan untuk kepentingan aktivitas anak, 
serta yang dapat dilakukan anak dalam kehidupannya. Enjoyable: pengajaran materi dan materi yang dipilih diupayakan mampu membuat anak senang, menikmati dan mau mengikuti dengan antusias. Mudah ditiru: materi yang disajikan dapat dipraktekkan sesuai dengan kemampuan fisik dan karakter lahiriah anak.

Nilai-nilai religius yang dikembangkan/ditanamkan pada diri anak dilakukan melalui pembelajaran yang bertujuan menanamkan nilai-nilai keislaman, antara lain anak diajari membaca kalimat syahadat, hafalan surat-surat pendek, doa-doa harian, hafalan hadisthadist pendek, hafalan asmaul husna, bacaan-bacaan shalat, dan kegiatan-kegiatan lain sejalan dengan hari-hari besar agama Islam. Pelaksanaan pengembangan nilai-nilai keagamaan dilaksanakan secara rutin sekaligus perkembangannya dipantau, dicatat dalam buka laporan perkembangan anak yang disampaikan kepada orangtuanya.

Selain itu juga dilakukan pembinaan busana islami.Hal ini dilakukan untuk menggali kepribadian muslim-muslimah di kalangan anak-anak dari sisi busana yang dikenakannya.Puncak dari binaan sekolah, seringkali mengikuti kegiatan lomba "Fashion Show" yang dilakukan dalam berbagai acara.

Pengembangan aspek religius dilakukan antara lain berupa ibadah ta'aluh.Ibadah Ta'alub merupakan karakter yang ditanamkan dalam pelaksanaan pengembangan karakter kepribadian religius dengan menekankan pada kegiatan yang bertujuan menanamkan nilai-nilai keagamaan pada diri anak.Pelaksanaan pengembangan nilai karakter yang dilakukan pada aspek nilai-nilai keagamaan melalui hafalan doa-doa sehari-hari, hafalan hadist-hadist pendek, berlatih bacaan shalat dan praktik melaksanakan shalat pada siang hari/jam 12.00 .

Pengembangan kepribadian Islami dilakukan melalui kegiatan berdoa sebelum memulai kegiatan, hafalan surat-surat pendek, hafalan doa-doa sehari-hari, latihan adab berwudhu berikut do'anya, shalat dhuha secara berjamaah, shalat Dhuhur secara berjama'ah dan aktivitas keagamaan lainnya seperti memperingati hari-hari besar Islam. 
Pengembangan Karakter Kejujuran, Keberanian mengambil risiko, Kecerdasan, Ketangguhan, Kedemokratisan, Kemandirian dan Kepedulian, serta Berpikir logis, kritis, kreatif, dan inovatif

Pengembangan karakter anak pada aspek kejujuran juga menjadi pilar penting pembentukan akhlak anak. Sebagaimana terjadi di PAUD Terpadu Aisyiyah Insan Robbani Muntilan, PAUD BIAS Muntilan maupun PAUD/TK Islam Terpadu Ibnu Hadjar Sirahan, bahwa pelaksanaan pengembangan karakter kejujuran dilakukan dengan mengajarkan anak untuk tertib dalam banyak hal, antara lain ketika anak-anak akan makan, minum dari bekalnya masing-masing harus sesuai dengan bawaannya, memakai baju ganti sebelum shalat dhuhur juga sesuai baju miliknya sendiri

Pengembangan kepribadian jujur sebagai aspek ketujuh dari akhlak aplikatif yang diajarkan di PAUD BIAS, dilakukan melalui kegiatan yang sama sebagaimana dilakukan di PAUD Terpadu Aisyiyah Insan Robani Muntilan. Keadaan yang sama terjadi di PAUD/TK Islam Terpadu Ibnu Hadjar Sirahan, bahwa pengembangan karakter kepribadian pada kejujuran ditanamkan dengan menggunakan sesuatu yang merupakan miliknya sendiri. Bentuk penanaman kemandirian dan tanggung jawab dilakukan melalui pemberian tugas sebagai petugas pada kegiatan upacara, memimpin doa memulai kegiatan belajar, memimpin shalat dhuha berjamaah, memimpin shalat dhuhur berjamaah, yang diberlakukan kepada anak-anak laki-laki.

Dapat disimpulkan bahwa pengembangan karakter kepribadian pada aspek kejujuran, kemandirian dan tanggung jawab dilaksanakan oleh PAUD Terpadu Aisyiyah Insan Robbani Muntilan, PAUD BIAS Muntilan dan PAUD/TK Islam Terpadu Ibnu Hadjar Sirahan Salam, melalui berbagai kegiatan yang nyata-nyata menanamkan nilai-nilai tersebut dengan kegiatan yang hampir sama. 


\section{Pengembangan karakter Kepemimpinan, Percaya Diri, Kerjasama, Kerja Keras dan Tanggung Jawab}

Pengembangan karakter kepribadian pada aspek kepemimimpinan, kerja keras dan tanggung jawab dilakukan di di PAUD Terpadu Aisyiyah Insan Robbani Muntilan, PAUD BIAS Muntilan maupun PAUD/TK Islam Terpadu Ibnu Hadjar Sirahan, Salam dilakukan melalui berbagai kegiatan di sekolah. Kegiatan-kegiatan tersebut antara lain seperti menugaskan memakai baju adat pada karnaval peringatan HUT kemerdekaan RI yang ke 71 dalam rangka membentuk sikap tanggung jawab, percaya diri dan kepemimpinan, mengikuti berbagai lomba dalam rangka membentuk nilai percaya diri dan kerja keras, mengikuti kegiatan field trip, dalam rangka membentuk kepemimpinan, mengajarkan ketrampilan membuat kue dalam rangka menanamkan sikap kerjasama dan kerja keras dan kegiatan-kegiatan lain yang disiapkan oleh sekolah untuk menanamkan karakter kepribadian kepada para siswanya.

Sejalan dengan yang dilakukan oleh PAUD Terpadu Aisyiyah Insan Robbani Muntilan, PAUD BIAS Muntilan mengembakan karakter kepribadian kepemimpinan, Percaya Diri, Kerjasama, Kerja Keras dan Tanggung Jawab, dilakukan melalui kegiatan field trip ke berbagai tempat seperti Taman Kupu-Kupu di Borobudur, orientasi lapangan ke tukang tambal ban untuk mengenalkan dan menanamkan sikab kerja keras, ke taman/pasar ikan Desa Ngrajeg dalam kerangka menanamkan nilai kerjasama, kerja keras dan tanggung jawab bekerja sebagai kepala keluarga, ke alam bebas dalam rangka mengamati bertiupnya angin untuk mengenalkan lingkungan sekaligus mengenalkan sain bagi anak-anak.

Pada PAUD/TK Islam Terpadu Ibnu Hadjar Sirahan, Salam pengembangan karakter kepemimpinan, dilakukan melalui pembinaan secara bergilir bagi semua anak untuk memimpin doa, berbaris masuk kelas, membawa jatah (bagian) snack untuk makan ringan di sekolah, sementara yang membagi snack adalah para ustadzahnya, peralatan makan minum anak-anak memiliki sendirisendiri. Berbagai kegiatan tersebut dilakukan dengan doa, atau nyanyian yang memimpin adalah anak yang telah ditunjuk. 
Mencermati berbagai fakta di atas, dapat disimpulkan bahwa pelaksanaan pengembangan karakter khususnya aspek kepemimpinan, Percaya Diri, Kerjasama, Kerja Keras dan Tanggung Jawab, dilaksanakan dengan berbagai cara sesuai dengan garis kebijakan sekolah/PAUD, namun secara umum kegiatan mereka sama.

\section{Strategi Pengembangan Karakter Kepribadian Anak Di PAUD Islam Terpadu Kabupaten Magelang Tahun 2015}

Strategi pengembangan karakter kepribadian anak menunjuk pada pada cara baqgaimana nilai-nilai karakter kepribadian ditanamkan kepada anak-anak. Menurut keterangan Ustadah Atun, ada berbagai cara/metode yang dipakai dalam menanamkan kepribadian anak khususnya di PAUD Terpadu Aisyiyah Insan Robbani, yaitu metode bermain, nasihat, keteladanan, hukuman, metode pembiasaan dan lain-lainnya.Metode-metode tersebut tidak bisa berdiri sendirisendiri melainkan saling terkait satu dengan yang lain. Penerapan metode atau cara dalam mengembangkan kepribadian anak dilakukan secara silmultan, misalnya ketika menerapkan metode hukuman diiringi dengan metode nasihat.

Sejalan yang terjadi di PAUD Terpadu Aisyiyah Insan Robbani, bahwa metode-metode dalam pengembangan karakter kepribadian anak dilakukan dengan bermain sambil bernyanyi, memberikan tauladan yang baik, memberikan nasihat kebaikan, memberikan hukuman bagi yang salah, membiasakan hal-hal yang baik, melakukan pengawasan terhadap kegiatan anak, dan sebagainya. Penggunaan metode-metode tersebut tidak dilakukan secara terpisah melainkan secara bersimultan.

Penggunaan metode-metode dalam mengembangkan karakter kepribadian anak sebagaimana tersebut di atas juga dilakukan pada pelaksanaan pengembangan karakter kepribadian di lingkungan PAUD/TK Islam Terpadu Ibnu Hadjar Sirahan.Dalam mengembangkan karakter anak, pihaknya menggunakan metode nasihat, pemberian contoh yang baik, pembiasaan, hukuman, metode permainan dan pengawasan kegiatan anak. Adapun penggunaan 
metode-metode tersebut antara lain terdeskripsi sebagai berikut, Metode Bermain, Metode Keteladanan, Metode Pembiasaan, Metode Nasehat, Metode Perhatian/pengawasan.

Penggunaan metode/strategi dalam mengembangkan karakter kepribadian anak dilakukan secara simultan/saling melengkapi antara metode satu dengan metode yang lain. Oleh karena itu, tidak ada satu metode-pun yang paling efektif dalam mengembangkan karakter kepribadian dilingkungan anak-anak PAUD.

\section{Kendala-Kendala Dalam Pelaksanaan Pengembangan Karakter Kepribadian Anak Di Paud Islam Terpadu Kabupaten Magelang Tahun 2015}

Kendala-lendala yang dialami oleh para ustadzah dalam mengembangkan kepribadian anak yang berkarakter antara lain pada saat orang tua tidak sejalan dengan pihak sekolah. Kendala dalam pengembangan karakter kepribadian anak ketika anak-anak diminta membawa bekal makanan dan minuman, beberapa anak tidak membawa karena orang tuanya tidak menyiapkannya.Hal ini yang pada saat kegiatan makan dan minum bekal bawaannya ada anak yang harus disendirikan untuk disiapkan makanan dari sekolah.

\section{Kesimpulan}

Nilai karakter kepribadian yang dikembangkan pada masing-masing PAUD mengacu pada pedomannya masing-masing. PAUD Terpadu Aisyiyah Insan Robbani Muntilan dan PAUD Islam Terpadu Ibnu Hadjar Sirahan Salam mengacu ketentuan pelaksanaan Pendidikan Karakter yang ditetapkan oleh Kementerian Pendidikan Nasional, sementara PAUD BIAS Muntilan mengembangkan nilai-nilai karakter kepribadian berdasar nilai yang ditentukan pihak sekolah, yakni 18 akhlak aplikatifnya. Pelaksanaan pembentukan karakter di PAUD Terpadu Aisyiyah Insan Robbani Muntilan, PAUD BIAS Muntilan dan PAUD Islam Terpadu Ibnu Hadjar Sirahan Salam dilakukan sebagai upaya pembentukan karakter kepribadian anak. Semua 
guru/pengasuh/Ustadzah melibatkan diri dalam proses pelaksanaan pengembangan karakter kepribadian anak di lingkungan sekolahnya masing-masing. Strategi pengembangan karakter kepribadian anak pada PAUD Islam terpadu di Kabupaten Magelang dilakukan sebagai bagian pengembangan karakter kepribadian anak, yang dilakukan dengan berbagai metode, meliputi metode bermain sambil bernyanyi, metode keteladanan, metode nasihat, metode pengawasan dan metode pembiasaan. Kendala-kendala dalam pengembangan kepribadian anak pada PAUD Islam terpadu di Kabupaten Magelang, khususnya faktor dukungan orang tua terkait dengan kebijakan sekolah dalam pengembangan karakter kepribadian anak.

\section{Daftar Pustaka}

Adek. 2015. Teori Perkembangan Kognitif Vigotsky. Online. http:// valmband.multiply.com/journal/item/11?\&show_interstitial=1 $\& u=\% 2 F j o u r n a l \% 2 F i t e m$. Diakses Juni 2015.

Arief, A. (2002). Pengantar Ilmu dan Metodologi Pendidikan Isl $\square \mathrm{m}$, Jakarta: Ciputat Pers.

Anita Yus, 2011. Model Pendidikan Anak Usia Dini,Jakarta: Kencana Prenada Media Group.

Ari Ginanjar Agustian. 2005. ESQ: Emotional Spiritual Quotien. Jakarta: Arga.

Danim, Sudarwan. 2011. Perkembangan Peserta Didik, Bandung: Alfabeta.

Desmita. 2010, Psikilogi Perkembangan, Bandung: PT Remaja Rosdakarya.

Goleman. 2003. Destructive Emotions: A Scientific Dialogue with the Dalai Lama, Bantam Books.

Heidi Murkoff, Arlene Eisenberg, Sandee Hathaway .2002.What to Expect When You're Expecting. Workman Publishing Company

Isjoni. 2009. Model Pembelajaran Anak Usia Dini. Bandung: ALFABETA 
Lickona, Thomas,Eric Scap and Chatarine Lewis. 2010. 11 Principles of Effetive Character Education, Woshington: Character Education Patnership.

Mansur.2009. Pendidikan Anak Usia Dini Dalam Islam. Yogyakarta: Pustaka Pelajar.

Megawangi, Ratna. 2004. Pendidikan Karakter, Solusi Tepat untuk Membangun Bangsa. BP Migas: Star Energy.

Megawangi, Ratna. 2010. Pengembangan Program Pendidikan Karakter di Sekolah; Pengalaman Sekolah Karakter. Makalah. IHF,JKT .

Mussen, Paul Henry. 19^^. Perkembangan dan Kebribadian Anak, Jakarta: Erlangga.

Musfiroh, Tadkiroatun. 2008. Memilih, Menyusun dan Menyajikan Cerita Untuk Anak Usia Dini, Yogyakarta: Tiara Wacana.

Monks, F.J. dkk.1992. Psikologi Perkembangan: Pengantar dengan Berbagai Bagiannya, Yogyakarta: Gajah Mada Unisersity Press.

Papalia, Diane E, Etc. 2008.Human Development (Psikologi Perkembangan, terjemahan A. K. Anwar). Jakarta: Kencana Prenada Media Grup

Salman Harun. 1993. Sistem Pendidikan Islam, Bandung: Al Ma'arif.

Santrock, J.W. 2010. Psikologi Pendidikan, Jakarta: Kencana.

Sjarkawi. 2008. Pembentukan Kepribadian Anak. Jakarta: PT. Bumi Aksara

Ulwan, Abdullah Nashih. 2012. Tarbiyatul aulad fil Islām. (J. Miri, Penerj.) Jakarta: Pustaka Amani.

Zhao, Y.L., 2002. Extracurricular Activity: How Character Education in Conduct in China. (http://www.tandl.vt.edu/IA/pdf/2002/ Yalizhao.pdf 